Talking to the People and Shaping Revolution: The

Drive for Enlightenment in Revolutionary Russia

Sarah Badcock

University of Nottingham

Final submission to Russian Review, 18 May 2006

7,848 words excluding footnotes

9,985 words including footnotes 


\section{Talking to the People and Shaping Revolution: The Drive for Enlightenment in Revolutionary Russia}

Comrades! Public teachers! You gave the people literacy, now you must give them development! Make free Russia's conscious citizens out of yesterday's village philistines!

(From educational pamphlet, 1917) ${ }^{1}$

The Provisional Government and the soviets regarded the campaigns to make ‘yesterday's village philistines' into conscious citizens as pivotal to the success or failure of the new regime. Without popular support, their stated goals of overseeing democratic elections, keeping Russia in the war, maintaining food supplies and preventing civic disorder were unachievable. Ordinary people were to be educated so that they would understand their new duties and responsibilities, as well as their new freedoms. These attempts to educate the population about the new political climate and transform their cultural lives were regarded by educated society as their great opportunity to bridge the gulf separating them from Russia's ordinary people. ${ }^{2}$ The political elite sought to bring cultural transformation to ordinary people through literacy, political education and citizens' training (grazhdanskoe vospitanie). While educational literature recognised that mass political literacy could not be achieved in the short term, ordinary people had to understand the rudimentaries of political life if the forthcoming elections to the Constituent Assembly were to be meaningful. Ultimately, while cultural enlightenment campaigns engaged ordinary people in the national political sphere, they failed to win consensus on the nature and direction of the new regime. Ordinary people did not support the Provisional Government's 
programmes because they did not agree with their messages, not because they did not understand them.

This article uses a close study of the provinces of Nizhegorod and Kazan to explore the cultural enlightenment campaigns that went on across Russia, in towns, villages and factories. Both provinces had pockets of heavy industry, ancient and well-established capitals, and large areas dominated by peasant landholding, which enable us to see interactions between elites and populace in both urban and rural settings. Both provinces were considered to be part of Russia's fertile 'black earth' belt, and had correspondingly high levels of agricultural production. Kazan was notable for its large non-Russian population, foremost among which were Tatar, Chuvash and Cheremis, or Marii, peoples. These two provinces cannot be taken to be 'typical' of Russia as a whole, as the Russian Empire's regional diversity precludes the drawing of broad generalisations. Study of these two provinces does however allow us to explore regional and local manifestations of cultural enlightenment campaigns both in well developed provincial capitals, and in rural areas. In particular, we will focus on the ways in which local political elites communicated with their citizens, both urban and rural, in 1917.

This article intersects with the rich and developing recent historiography on relations between ordinary people and the political elite in the late Imperial and revolutionary periods, and on questions of citizenship. Scholars have become increasingly sensitive to the importance of educated society's cultural constructions of peasants. ${ }^{3}$ Drawing on this rich literature, my research has found that the political elite's perceptions of a 'backward' peasantry informed their relations with the rural population in 1917, as it had in the pre-revolutionary period. The political elite's cultural exclusivity cut ordinary people out of the elite's decision making process. 
This mirrors what Yanni Kotsonis found of agrarian policymakers in the prerevolutionary period, but is of particular importance in the democratised climate of the revolutionary period. In 1917 , the political elite's unwillingness to recognise peasants as autonomous political actors left them unable to integrate real peasant concerns into their policies, and contributed to the political elite's inability to mobilise the rural population to actively support their vision of the state. This problem cut across classes and parties, as liberals and socialists, workers and intelligentsia alike struggled to win active support from the rural population.

Orlando Figes' important article on peasant understandings of revolutionary language in 1997 encouraged historians of the revolutionary period to reconsider communications between the political elite and ordinary people. A number of recent works have developed, in different ways, the sense that ordinary people came into their own as political actors in the course of World War One. Joshua Sanborn has explored ordinary people's transformation from subjects to citizens in his work on military service, while Melissa Stockdale's work on women soldiers shows how ordinary women sought to participate in the defence of the nation as full citizens. In his work on adult education programmes, Scott Seregny has shown how ordinary rural people became increasingly engaged with national questions in the course of the First World War. ${ }^{4}$ Aaron Retish, in his study of the Viatka peasantry in the revolutionary period, found that peasants, alongside political elites, sought to shape and form a new political world. ${ }^{5}$ Michael Hickey's work on Smolensk in the revolutionary period has made sense of ordinary people's political behaviour, and shown them to be rational poltical actors. ${ }^{6}$

This article builds on these research findings that have interpreted ordinary people's understandings of the revolution in a more positive light, and that see 
ordinary people actively shaping their own notions of citizenship and their place in the nation. This study's focus on local issues and on 1917 in particular allows it to make a contribution to this discourse, as it exposes the ways that ordinary people appropriated cultural enlightenment programmes, and took over hegemony in the political sphere. We will start by outlining the identities and preconceptions of cultural enlightenment campaigners, and the disparities in their understandings of the rural population. This leads on to an analysis of the means utilised by the political elite to communicate with ordinary people. Finally, this article will look in detail at Kazan's grain producers, whom cultural enlightenment campaigners strove, and ultimately failed to 'educate' on the efficacy of the grain monopoly. ${ }^{7}$ I argue that there were clear and effective paths of communication between the political elite and ordinary people, and that ordinary people engaged actively in the political sphere. The political elite's programmes were formed from the notion of an ignorant, childlike, unresponsive rural population, and they failed to respond to ordinary people's real political needs. Ordinary people consciously rejected the elite's political vision and its proposed cultural transformation. In so doing they condemned the Provisional Government's democratic dreams to failure.

\section{Transforming Philistines}

Cultural enlightenment campaigns addressed peasants, workers and soldiers in towns and in the countryside. In Nizhegorod and Kazan, the cultural enlightenment campaigns were dominated by the town- based soviets of workers' and soldiers' deputies, and though they were actually most active in urban areas, their rhetoric targeted the rural population specifically. A wide range of different organisations and institutions threw themselves into cultural-enlightenment work in 1917, headed by the Provisional Government and soviets. At local level, the regional soviets played the 
most important role in funding, organising and co-ordinating cultural enlightenment campaigns. Though these groups harboured very different aspirations regarding the outcome and content of cultural enlightenment, they all contributed to the general goals of literacy, political education and cultural transformation. As Dan Orlovsky has shown, the Provisional Government addressed cultural and educational issues from its inception, but essentially did no more than encourage and expand the prerevolutionary educational efforts of the zemstva in village primary education. Its goals, of general education and literacy, were very much in the pre-revolutionary liberal tradition, and did not envisage a profound transformation of cultural models. ${ }^{8}$ The activities that went on at local level in some respects reflected the Provisional Government's attempts, but were more ambitious, and sought to transform ordinary people's cultural landscape. The state-centred political elite that was willing and eager to use coercion identified in Peter Holquist's work did not feature among these local level cultural enlightenment campaigners. ${ }^{9}$

At local level, the soviet-led 'committees of cultural-enlightenment' were the most prominent organisation, and provided an umbrella for a diverse range of other public organisations that sought to become involved in cultural-enlightenment work. A wide range of groups involved in popular organisation played a part, running courses, meetings, literacy programmes and spectacles. To give an example of the range involved, eighteen different public organisations and political parties delegated representatives to the Kazan soviet's cultural-enlightenment section. They give us a good indication of the sectors of society involved in the dissemination of cultural enlightenment. They included the Society of public universities, the society of young teachers, Bolsheviks, Mensheviks, Socialist Revolutionaries, the party of independent socialists, workers' club, the Polish democratic organisation, the socialist committee 
of Muslims, the peasant group, student co-operative, union of teachers, union of military medical assistants, union of zemstvo employees, the society of Volga minority nationalities, the organisation of evacuated military in Kazan town, Kazan university and the women in higher education group. ${ }^{10}$ These groups defied straightforward class categorisations. Though they were predominantly intelligentsia in background, there were also large numbers of urban workers and soldiers involved in the campaigns.

Despite their diverse background, educators shared a conceptualisation of the role of educators in 1917 as an external influence, moulding and leading the so-called ‘dark people’ (temnyi narod) of Russia’s countryside. Both Provisional Government and soviet sources demonstrate this attitude towards the enlightenment campaigns, and it was targeted specifically at the rural population. The political elite perceived the drive for enlightenment in the countryside as an alien imposition, and in no way an organic development. Provisional Government intellectuals saw rural enlightenment campaigns as 'the imposition of an alien world upon little-understood peasants' ${ }^{11}$ This lack of connection with rural life cut across class delineations, and was felt by the 'democratic' soviets as well as by the 'bourgeois' Provisional Government. The cultural enlightenment commission of the soviets of soldiers and workers' deputies in Nizhnii Novgorod published a frantic appeal in August for assistance in the task of 'bringing light to the darkness':

Working intelligentsia of Nizhnii Novgorod! If you have free time, and you want to use it in the struggle with darkness, take part in the work of the enlightenment commission of Nizhegorod soviet of workers and soldiers' deputies. In this terrible hour, the living word of enlightenment can carry out true struggle with the darkness that is our bitterest enemy... ${ }^{12}$ 
The soviet's appeal has an apocalyptic and evangelical feel, of enlightenment as an externally led crusade against the forces of darkness within village life. This corresponded with the views expressed by the Provisional Government led bodies. Enlightenment campaigns usually originated in town based organisations. The 'gulf' to be spanned was not between educated society and the people (narod) so much as between urban and rural cultures. Much of the contemporary debate centred around how the enlightenment campaigns could penetrate the villages more successfully, and why their successes seemed so limited. The very positioning of enlightenment as an external force offers one powerful explanation. The outsider bringing knowledge and light into the benighted villages was not a model that lent itself well to engaging with ordinary people.

Party politics saturated the political elite in 1917 , and this was reflected in cultural enlightenment campaigns, despite the emphasis in educational literature that cultural-enlightenment programmes should be non-partisan in their treatment of political issues. ${ }^{13}$ It is a reflection of the mood of 1917 that cultural enlightenment literature was exclusively socialist, and assumed socialist development as both necessary and beneficial. None of the mainstream cultural enlightenment material propounded a liberal-capitalist perspective. This reflects the hijacking of 'democracy' by socialist parties, and the direct association of democracy only with socialism. ${ }^{14}$ The main socialist parties all affiliated with the soviet's cultural enlightenment section in Kazan and Nizhegorod, and some of them operated very effectively as educators, particularly when they utilised existing networks of support. The Socialist Revolutionary Party (PSR) was the only mainstream party to concern itself directly with the rural population, and to have a strong base of rural support. As such, the PSR offered the possibility of cultural enlightenment campaigning that spoke more directly 
to the needs of a rural audience. The PSR campaigned actively in Nizhegorod and Kazan, and its efforts were not restricted to narrow discussion of the party programme, but encompassed more general themes. At meetings held by the PSR in Nizhegorod guberniia during 1917, the topics covered were wide ranging and reflected the topics covered by cultural enlightenment literature. ${ }^{15}$

Educational campaigns were undertaken by the disparate groups associated with the political elite in the heartfelt belief that education could 'transform' Russia's population into newly fledged democratic citizens, who could participate in the building of an egalitarian, even utopian, state. They sought to re-forge Russia's ordinary people in a new form, to replace old cultural forms and norms with urban, enlightened and democratic values. This emphasis on 'transformation' lies at the heart of the problems for Russia's political elite in 1917. The new revolutionary regime required conscious citizens, but the political elite did not recognise the majority of Russia's ordinary people as conscious citizens. They were 'philistines', who needed to be taught, corrected, tutored, guided.

Cultural enlightenment campaigns sought to increase the opportunities for reading and learning available to Russia's working population, urban and rural. This aspect of the campaigns built on pre-revolutionary activities like workers' schools and societies for adult education, and the formation of 'popular universities' in the prerevolutionary period. ${ }^{16}$ Unlike the pre-revolutionary educators, however, 1917's cultural enlightenment programmes sought to transform the cultural world for ordinary people. The establishment of libraries and 'people's houses' (narodnyi dom) in towns, and reading rooms in villages were intended to facilitate this cultural transformation. ${ }^{17}$ The importance of such establishments was not just as a place to access books, but also as an environment for learning, and as a social space to interact 
with other conscious citizens. The ambitions of educational campaigns to draw ordinary people into the sphere of civil life were made explicit. The instilling of citizens' values was inseparable from the more straightforward objective of improving literacy levels and access to books. Public libraries and spaces were to provide a new forum for conscious, civilised Russia. Existing public gathering spaces of bars and taverns were explicitly challenged by these new, more worthy meeting places: There must be a tearoom in the narodnyi dom, where local residents can go to sit in their spare time, have a chat with one another. At the moment, people go to the tavern or the teashop, which is like a tavern; the cursing in such teashops is heard ceaselessly, it's dirty all around, vodka or spirit is often drunk there. The tearoom in a narodnyi dom is not like that at all; it's clean, bright and comfortable, there are no drunkards, no swearing; there are newspapers and journals on the table. There one is enticed to rest and to peacefully chat with one another...18

This statement of aspiration for the narodnyi dom reveals much of what the cultural enlightenment campaigns sought to address. Swearing, dirt and alcohol were all implicitly identified as undesirable aspects of Russian life that needed to be reformed. This was not a matter of giving skills of literacy in order that people could form their own ideas and make their own political decisions. The aim was rather a total transformation of societal norms and behaviour. There are clear continuities from the pre-revolutionary aspirations of educators, who sought not just to impart literacy but also to transform society. ${ }^{19}$ The establishment of narodnyi dom at volost and uezd levels usually by the newly formed committees of public safety can be seen in this context, as attempts to shape the peasant class anew. It is hard to envisage them living up to their lofty ambitions. ${ }^{20}$ Ordinary people sought to be informed about the new political climate, while the political elite sought to transform their cultural world, and to define their relationship with the revolutionary state. 


\section{THE 'DARK' PEOPLE?}

Contemporaries interpreted the failure of some aspects of the elite's education programmes as evidence of the ignorance and unculturedness of the Russian population. The 'dark', 'uncultured' 'ignorant' nature of ordinary people, particularly in the villages, were consistent tropes used by the political elite. This figurative language helps us understand the attitudes that the political elites took towards those they sought to educate. The political elite's deep seated and self perpetuating belief in rural backwardness served only to alienate and distance them from ordinary people. ${ }^{21}$ The Kazan soviet of workers, soldiers and peasants' deputies' cultural enlightenment section offers a typical expression of this desire to instil political literacy among ordinary people; 'Democracy will only be invincible when it is formed from itself, and organised into one united army. For this it is necessary that all the labouring masses (trudiashchiisia massa) are deeply inspired by conscious public interests and have fixed ideas about their aims. ${ }^{22}$ The language of this statement is combative and determined, demanding as it does that ordinary people consciously embrace "public interests', to be defined by the soviet itself. Cultural enlightenment campaigns sought to prescribe to ordinary people the definition of their best interests. Through this, the political elite sought to direct the course of the revolution.

The pervasive negative attitudes of the political elite towards the rural population reveal how deluded they were in their conceptions of the rural population. Parallels with the 1873-4 'Going to the people' (khozhdenie v narod) show that the attitudes of the political elite towards ordinary people were relatively unchanged over the intervening forty-five years. The 'Going to the people' movement describes the actions of some thousands of intelligentsia, mainly students, who went to live and work in the countryside in order to spread the gospel of revolution among peasants, 
and thus to pay back the 'debt' owed to the peasantry. Both in the 1870 s and in 1917, enlighteners aimed for a utopian transformation of the state, and an attempt to bridge the gulf between educated society and ordinary people. ${ }^{23}$ The Populists of the $1870 \mathrm{~s}$ sought to resolve the conflict between state and society by using the might of the peasantry to transform the state through revolution. In 1917, however, the political elite sought to draw the peasantry into a new civil society that would solidify the revolutionary transformation of the state. ${ }^{24}$ Though by 1917 there were significant developments away from the perceptions of the 1870s, many underlying assumptions continued to reflect much older ideas about the nature of the peasantry, and on essentially hierarchical understandings of culture. ${ }^{25}$ The most important of these was the idea that the peasantry was essentially 'dark', unable to escape from their poverty with their own intellectual resources, and that they required external agents to lead them out of their benighted position. ${ }^{26}$

Ordinary rural people to some extent themselves perpetuated these conceptions of the dark countryside. The change of regime presaged by the February revolution unleashed a barrage of proclamations, appeals, newspapers, leaflets and pamphlets into the villages. A prominent feature of reports and documentation from the villages was the appeals and comments from the peasants themselves commenting on their 'darkness' and ignorance of current affairs, and their requests for assistance in understanding current events. Such self-descriptions of 'darkness' from the villagers cannot be taken at face value. Peasants themselves utilised stereotypes of the 'dark peasantry' in their discourse with educated society, but we cannot impute from this that the peasantry were actually ignorant and childlike. It was rather that they utilised understood tropes as the most effective means of communication. ${ }^{27}$ Despite this caveat, reports from the villages repeatedly stressed the need for educated people to 
come to the assistance of the rural population. Soldier deputies from the Nizhegorod soviet of workers' deputies travelled around Sergachskii uezd in May. Their reports in the soviet newspaper described the archetypal 'dark' countryside:

Peasants complained that they were forgotten by the town and didn't know anything; wanted to know everything about past and forthcoming events. Newspapers and leaflets are needed. Among listeners were eighty year olds as well as seventy year olds. In general one has to say that there was virtually no youth in the countryside and in the villages youth was not seen at all. ${ }^{28}$

By 1917, the Russian village was no longer the hermetically sealed nineteenth century enclave that the political elite envisaged. Villages had been increasingly 'opened' to outside influences, and peasants were drawn into the public sphere by the turn of the century, ${ }^{29}$ facilitated by the spread of literacy and education. ${ }^{30}$ The outbreak of World War One and accompanying mass mobilisation intensified village connections with the outside world, as it exposed a significant proportion of young men to the wider world, and gave the village population a new incentive to engage with national issues. ${ }^{31}$ The war transformed national politics into a sphere intricately associated with peasants' daily lives. ${ }^{32}$ In conscripting young men, wartime mobilisation removed the most literate segment of the village community, ${ }^{33}$ making the skills of literacy a precious commodity. ${ }^{34}$ The rural intelligentsia, who were targeted by the political elite as the ideal harbingers of enlightenment in the countryside, had exactly the skills of literacy that villages apparently cried out for. They should have been the perfect agents for enlightenment. The rural intelligentsia was specifically mentioned in appeals from villagers to help them understand current events. The elder of Khvostikovskii volost executive committee, Semenovskii uezd, appealed specifically to those individuals who lived in the volost but were not strictly 
members of the commune, such as priests, teachers and shop managers, to take part in a meeting held on 14 March to form the volost executive committee and the volost militia. ${ }^{35}$ Despite this appeal, of the twenty-three members of the Khvostikovskii volost executive committee subsequently formed, all but two (the volost scribe and a housekeeper) were peasants. All were men. ${ }^{36}$ Local male peasants dominated the village's formal political power structures in 1917. Despite an apparent awareness from peasants of the need for rural intelligentsia involvement, the domination of the new administrative structures by male peasants perpetuated traditional village power structures. The rural population did not allow the rural intelligentsia hegemony in village life.

\section{TALKING TO THE PEOPLE}

The political elite utilised a range of means in communicating with ordinary people in 1917. Though they perceived that their most serious barriers in transforming society was how they could communicate their message to ordinary people, especially in the countryside, we see that language was not an insuperable barrier for educators in the countryside. Much of 1917's educational literature focused on the means that could be used to communicate with the rural population, and to bridge the gulf between the language of the villages and the language of the revolution, which often utilised abstract or foreign terminology. Orlando Figes wrote about the purported gulf between peasant understandings of the revolution and the world around them, and the understandings and expectations of their would-be educators. This issue of communication with ordinary people is an important one, which requires further exploration. Michael Hickey's work on worker and soldier activists in the villages has already shown that at least some rural agitators spoke to peasants in language they understood. ${ }^{37}$ Educational literature produced specifically to guide educators in their 
activities contained genuine and well grounded attempts to conduct educational activity in language and in forms that would be understood and accepted in the villages. Figes used a number of anecdotes taken from educational literature of peasant ignorance about key revolutionary words and concepts, alongside the reports of State Duma deputies visiting the countryside in the first three months after the February revolution. ${ }^{38}$ These anecdotes do not prove that peasants did not understand the language of 1917, but showed rather that educators were aware of the limitations and desires of their audience. Educational literature offered diverse alternatives of how to best communicate with rural people. Cultural enlightenment events were held regularly and enjoyed enormous popularity in towns and countryside.

Educational literature stressed the need to adopt emotional, localist and nonconceptual arguments when addressing a peasant audience. The examples given in the educational literature and used by Figes of how peasants misunderstood foreign words and concepts were given specifically so that such pitfalls could be avoided. Lecturers were beseeched to speak in accessible and engaging ways:

You must force your listeners not only to listen, but also to experience everything you speak about, not just to understand, but also to feel. For this, your exposition must be clear and simple; the argument must occupy a lesser place in your words as far as is possible, attention must be paid predominantly to examples, and especially examples from regional life. ${ }^{39}$

Lecturers were warned specifically not to use foreign or unfamiliar terms in their speeches, to illustrate them profusely with living examples from Russian peasant life, and to engage not so much in lectures as in conversation with the listeners. Questions from the audience were answered in an informal way, by 'going down into the crowd of listeners, and when receiving a question from an individual, answer very loudly, so that the answer could be heard by other people around. ${ }^{40}$ Cultural 
enlightenment literature left nothing to chance. Specific examples were given of how to respond to common questions, and how to explain abstract concepts in terms that peasants would understand.

The political elite recognised that literacy campaigns needed to cater for the non-Russian community as well as to ethnic Russians. Real efforts were made to educate and communicate with non-Russians in 1917. Kazan's non-Russian population, including Tatars, Chuvash and Cheremis, all with different languages and alphabets, posed a particular challenge. These groups were regarded by the local political elites as the 'darkest' elements of the rural population, and the most difficult to reach. The Tatar community had a history of hostility to state and external influences. From 1827 onwards, clumsy efforts had been made by the state to convert apostatised Tatars, and defectors were forcibly resettled or exiled. This experience left the Tatar community particularly hostile to state intervention. ${ }^{41}$ Attempts to access non-Russian rural communities were hindered by a shortage of personnel with the necessary language skills and cultural awareness. The army provided more fertile ground for cultural work. The literacy school set up by the soviet's cultural enlightenment committee and officers and soldiers of the $94^{\text {th }}$ regiment stationed in Kazan town, for example, opened four schools for the regiment, divided by nationality; Russian, Tatar, Ukrainian and Chuvash. Of the 557 identified illiterates in the regiment, 227 enrolled in the schools, while the school's teachers came from the ranks of the officers and soldiers themselves. ${ }^{42}$ The ethnic divisions here reflect an important aspect of cultural enlightenment activities in Kazan. This example also blurs the distinction between educators and pupils, as teachers and pupils lived and worked together. 
Educational campaigns were not restricted to speeches, written material and general haranguing in their attempts to communicate with ordinary people. Aaron Retish has shown how the political elite in Viatka province utilised ceremony, public holidays and their links with the Orthodox Church to educate the population, and through this education to dictate the form of revolutionary citizenship. ${ }^{43}$ used a broad range of means in its quest to culturally transform Russia, including theatre, songs and spectacles. As with other fields of activity, these activities were continuations of prerevolutionary elite activities, ${ }^{44}$ and used symbols and means that were familiar to their audience. The more elaborate media of spectacle and theatre were most frequently seen in urban settings, since towns provided a larger audience and more amenable environment for such activities. In urban settings, there were a range of commercial entertainments on offer whose outputs overlapped with the explicitly culturalenlightenment activities organised by the political elite. In the villages and countryside, more limited avenues of enlightenment were utilised, but they were varied none the less.

A striking feature of cultural enlightenment work was the way in which the wholesome messages it wished to convey were sweetened with music and simple joys. Singing, theatre, public spectacles and funfairs were all regarded as important vehicles for the enlightenment process. These forms of entertainment tell us about how ordinary people used familiar, symbolic and entertaining forms of expression, as well as about how the political elite sought to construct these forms. The celebrations held by the $164^{\text {th }}$ regiment in Kazan in commemoration of the revolution used colour, song, music and group activities to engage with its audience. For the occasion, on 9 April, the barracks were carefully decorated with pictures, placards and flags. General Myshlaevskyi, commander of the region, watched the regiment perform manoeuvres, 
then the band played the marseillaise. There was a succession of speeches, and the regiment shouted 'URA!' repeatedly together. In the evening, there was a 'diversion', with music, songs and verses, and the evening was ended with a display of fireworks. ${ }^{45}$ Though on one level, these events were 'simple pleasures', and straightforward entertainment, on another they offered a forum for ordinary people to learn about and identify with the new regime.

Among the most frequent events held in the towns were general spectacles, variously called 'funfair-lottery-concerts' (narodnoe gulian'e-loteriia-kontserti). In Nizhnii Novgorod, for example, the soviet of workers and soldiers' deputies organised a 'grand funfair-lottery-concert' to raise funds for the soviet, held in the gardens of the Kremlin (renamed the 'Gardens of Freedom') on the last Sunday in May. This started with a morning of 'children's events', then progressed to a lottery, cinematograph, buffet, and concluded with 'grandiose fireworks' ${ }^{46}$ The entrance fee raised significant funds for the soviet. Spectacles of this nature were features of Kazan's cultural life too. The Kazan soviet's cultural enlightenment section held a fund raising day for the soviet on 10 September that involved a succession of concerts, spectacles, bazaars and lotteries. An orchestra played military music all day long, which 'was a great success', and the halls were decorated with flowers, greenery and coloured lights. ${ }^{47}$ These spectacles were not just fund raising events. By engaging with the population in this way, campaigners sought to create an alternative set of rituals, and to establish a fresh cultural environment that could move ordinary people away from the dirty, 'uncultured' teashops and taverns that were the alternative focuses of Russia's popular cultural life.

The efforts of the soviet's cultural enlightenment section were supplemented by events organised by a whole range of other groups. In Kazan, for example, the 'old 
PSR group' organised a number of grand 'revolutionary evenings' that offer some indication both of the diversity and the popularity of these events. The 'revolution evening' held on 26 April was extensively advertised, and boasted a guest appearance from Ekaterina Breshkovskaia, as well as a 'no-loss' lottery, two orchestras, a theatre of miniatures, a 'cloth village', drama, comedy, cabaret, diversions and pictures. ${ }^{48}$ The tickets were all sold by 13 April, and a second showing was offered for the 27 April in response to demand. ${ }^{49}$ The day after the event, a fiercely critical letter about the event was printed in the local soviet newspaper Kazanskaia rabochaia gazeta. Breshkovskaia had not attended, there had been extensive speeches from senior regional SRs, and the character of the evening had been a political propaganda opportunity rather than an evening's light entertainment. As if that were not enough, it was alleged that the verses recited were pre-revolutionary, and praised Nicholas II! The organisers were forced to address the discontented audience directly, and rather provocatively suggested that 'if you don't like it, you can leave'. ${ }^{50}$ This is an illuminating exchange, and offers rare feedback on the reception of such events. The hostile response of the public leaves no doubt that they were a highly critical and aware audience, who had high expectations and were not fobbed off with thinly veiled educational material.

Concerts and theatrical performances were frequent in Nizhnii Novgorod and Kazan towns, and were enthusiastically attended by the town's population. Some of these were commercial ventures, and some were commissioned by the soviet. Such performances attracted daily reviews in the socialist press. ${ }^{51}$ There were precedents in the pre-revolutionary period of high cultural fare as vehicles for political education, ${ }^{52}$ and the relationship between popular opinion and commercial culture became more intense through $1917 .{ }^{53}$ Educational literature was very specific in its suggestions of 
how to stage plays as part of cultural enlightenment programmes. In theatre, efforts were made to make these cultural experiences as accessible as possible for audiences not necessarily familiar with theatre. Plays were to be amusing, not too long and sufficiently simple that they could be effectively staged with a small cast, and without expensive and complicated props. There were even plays written especially for revolutionary events that recounted the events of revolution in dramatic form, and that cast Kerensky in the leading role. ${ }^{54}$ Theatre became increasingly politicised, and scenes from the young revolution were added to new productions. ${ }^{55}$

These revolutionary diversions were not always very professional, but this only emphasised their 'democratic' nature. They also reiterate that these events were not always orchestrated by the political elite, but could reflect ordinary people's involvement in cultural enlightenment. At a soviet organised 'soldiers' evening' held in Nizhnii Novgorod to celebrate the first day of Easter a play was staged as well as singing and dancing. Workers as well as soldiers attended. A reviewer noted charitably that the first performers were 'not at all bad', and that with 'only a small effort' they became quite good. One of the performers, a chemist called Roznatovskii, was commended specially for his free and simple speech in his roles as Dan and Shulygin. ${ }^{56}$ These enlightening performances were a very prominent feature of city life; a glance at the advertising in newspapers shows that hardly a day went by without a performance of some description. Such amateur efforts are strong indications that some aspects of the cultural enlightenment literature were being observed; this was 'people's theatre', speaking to ordinary people in language they understood. ${ }^{57}$ They also reiterate that the political elite did not have hegemony in cultural enlightenment, and ordinary people themselves engaged in the process of bringing enlightenment and interpreting the revolution. 
The use of music as a means to engage ordinary people in educational efforts was well established. Listening to, and participating in, sung prayers was an integral part of the orthodox faith, and a part that many ordinary people enjoyed best. ${ }^{58}$ Medynskii's guide to establishing village cultural enlightenment activities proposed that any efforts should commence with the establishment of a village choir, and most programmes of entertainment and education involved music as well. ${ }^{59}$ The memoirs of N. Sukhanov, a deserter in 1917, describe how he organised a demonstration in Saralovskii volost, Laishevskii uezd, Kazan. He had planned a rousing chorus of the Marseillaise, but was thwarted as no one knew the words. ${ }^{60}$ There were also touring musical performances, which were hugely popular. The Volynskii regiment's orchestra, of which more than half the members had higher musical education, for example, visited Nizhnii Novgorod twice in the course of its national tour, and was enthusiastically welcomed. Their performance was supplemented by a meeting, at which political themes were addressed. ${ }^{61}$ Even without the addition of political meetings, these musical evenings carried political and ideological significance. Iakov Posen, the director of Kazan's town orchestra, responded to criticisms that his musical programme was too highbrow in a letter to the local soviet newspaper. Posen appealed to the newspaper's readers to tell him what was wrong with his musical programme, which included Robespierre's revolutionary overture, Chopin's funeral march, and pieces from Glazunov, Rimskii Korsakov and Kochetov. ${ }^{62}$ These musical performances were politicised, like other areas of cultural life, and exposed to popular criticism.

The sometimes elaborate manifestations described above were predominantly city-based events. Events were organised in the countryside, but they tended to be much simpler in form, reflecting the practical difficulties of organising in the villages. 
In towns, the political elite who orchestrated education campaigns drew on a pool of educated people and an existing network of cultural facilities such as theatres, public spaces and concert halls. Urban dwellers were liable to be better educated as a group, more culturally aware, and more amenable to education programmes. ${ }^{63}$ The process of enlightenment in rural areas raised specific problems. The rural population was geographically dispersed, which made it more difficult to reach, and were generally less cosmopolitan and had lower levels of formal education. To compound matters, there was a dearth of educated people to initiate such programmes in rural areas. That said, rural based events shared features with the more sophisticated city events, utilising music, colour, entertainment and group activities to mobilise participants. Demonstrations and celebrations of freedom and the revolution were held in many villages. They often involved a march around the streets of the village carrying coloured flags and placards, and concluded with speeches from prominent locals and outside agitators. The village priest frequently played an important role in such procedures, saying a prayer to open events. ${ }^{64}$ In Bolshe Akhmutov village, Sergachskii uezd, Nizhegorod guberniia, the priest even blessed the red flag with holy water in preparation for a visit by soldier deputies from the soviet. ${ }^{65}$ The participation of the priest offered villagers a reassuring air of continuity; just as he had led and participated in pre-revolutionary festivals and events, so his role in the revolutionary proceedings lent an air of normality to the new era. ${ }^{66}$

The most important, and most widely advertised, public holiday of 1917 was that called to celebrate May Day. This socialist holiday provided an opportunity for a wide range of public consciousness ranging activities. The socialist parties, alongside the soviet's cultural enlightenment section, played the most prominent role in bringing the celebrations to fruition. May Day, held on 18 April to coincide with the Julian 
calendar, was widely advertised and reported in the socialist press. Reports came in from towns and villages on the size and success of the May Day holidays. The holiday was imbued with different meanings according to the agenda of the organiser. Most widely, it was used to celebrate Russia's newfound political freedom, and to herald the unity of working peoples. At the celebrations held by the Sormovo and Kanavin factories in Nizhnii Novgorod, around 80,000 people attended, carrying 150 flags. $^{67}$ These banners defined the procession of the demonstration, and the banners denoted a range of different affiliations, with party devices an important feature of affairs:

Slowly and solemnly, in immaculate order, the dense columns of workers and citizens advanced. Every factory shop came forward separately with their banners, and every party section under the leadership of its representatives. The PSR's workers' and peasants' organisations presented their own especially beautiful picture. The whole banner was embroidered and painted with loving care with the party's devices and slogans- "In struggle you will get your rights", "Land and freedom" and others- these swayed over harmonious columns of thousands of organised comrades. In every hand, on every breast, in every buttonhole, were red bands, bows, ribbons with party initials and divisions. . .68

In Kazan, the dominant Menshevik group in Kazan tried to harness the goodwill generated by the event to solder over the factions in the Social Democratic party. ${ }^{69}$ The Kazan celebrations included a procession around town. The town's different party groups all formed, and were greeted with varying degrees of enthusiasm by the procession of workers and soldiers. ${ }^{70}$ As well as events organised by the soviet, political parties took advantage of the heightened political mood to hold meetings throughout the day. This was a forum for political competition as well as for working solidarity. There was hostility, for example, between the 'bourgeois' 'Ittifaku-Musilmin' (Tatar nationalist party) and the Muslim socialist committee, which held competing meetings throughout the day. ${ }^{71}$ The May Day celebrations 
provided a forum for ordinary people to participate in the new revolutionary state, and to hear the political elite's interpretations of the new political order.

\section{ORDINARY PEOPLE AS POLITICAL ACTORS}

The political elite clearly utilised a wide range of measures to communicate with ordinary people, and to engage them with, and educate them in, the new political order. Despite these apparently successful efforts, the political elite were unable to lead and direct ordinary people's interpretations of the new order.. The inability of the political elite to exercise leadership over ordinary people had serious and immediate implications for local and national government alike. Ordinary people were successfully drawn into the political sphere, and participated in regional and national elections. No amount of education, however, could convince ordinary people either to respect private property, or to accept what they perceived to be the unfair market established by fixed prices. I will conclude by exploring the political elite's unsuccessful attempts to implement of the grain monopoly in Kazan guberniia. The Provisional Government's grain monopoly, whereby all surplus was compulsorily purchased by the state at fixed prices, provoked hostility and non-cooperation in many uezds of Kazan, and resistance was particularly virulent in non-Russian regions. Attempts to win villagers' co-operation with education programmes routinely failed. Kazan uezd provisions administration, for example, reported to the guberniia provisions committee on 12 July that the population categorically refused to implement the grain monopoly, and that only strong military force could implement the grain monopoly. In a number of volosts, provisions educators were beaten and terrorised. Most communities refused to organise provisions committees, and where they did exist, as in Baltasynskii volost, they were re-elected and themselves opposed the grain monopoly. ${ }^{72}$ When a provisions instructor came to Baltasynskii in August, 
he was told to address 'requests' for fixed prices to the commune council, and the Tatar villagers said, 'we will submit to the law, but we won't submit to norms of consumption and fixed prices. ${ }^{73}$ This situation did not improve in the uezd. Kazan's uezd commissar wrote to the guberniia commissar at the start of September that he had met extreme hostility when trying to defend the grain monopoly in Kliuchei village, Kudmorskii volost, and had been forced to run away. ${ }^{74}$

Other uezds were even more violent and confrontational towards the educators sent to the villages. In Iadrinskii $u e z d$, where large quantities of grain were being illegally exported to neighbouring uezds, most volosts issued categorical refusals to carry out the grain monopoly or to organise volost provisions committees. In a number of villages, the mood was described as 'extremely dangerous' ${ }^{75}$ Representatives of the Kazan soviet of workers and soldiers' deputies visited Alikovskii volost, Iadrinskii $u e z d$, in an attempt to educate the population on the grain monopoly. A meeting was held in the Chuvash village Al'kov on 25 July. Around two thousand people attended, and when delegates began to speak of the need to organise committees, a crowd of around two hundred people, reportedly dominated by deserters armed with sticks and bottles, came forward and beat three of the delegates up. When the local intelligentsia, including teachers and a priest, protested at the violence, they were also attacked. Only one of the soviet delegates managed to run away. The disorder went on from ten in the morning till three in the afternoon. By the time armed assistance turned up at four in the afternoon, the crowd had mostly dispersed. Thirty-seven people were subsequently arrested and taken to Iadrinskii prison by an armed convoy of soldiers. ${ }^{76}$

The faith of Kazan's regional administration in the efficacy of education was understandably dimmed by the open resistance their programmes faced. In July, 
Kazan's united provisions meeting was forced to conclude that seizure of grain backed by armed force was the only way to extract grain from the region's peasants. ${ }^{77}$ This does not reflect a willingness to use coercion to implement policy, as Holquist argued, but rather was a measure borne of utter desperation, as local educators and administrators were physically attacked and threatened. Even then, the belief that education would resolve food supply problems was tenacious, and reluctance or refusal to use force against the population persisted. Alexander Kolegaev, leader of the Kazan SRs, and later a leading light of the Left SRs, travelled around Kazan's countryside in early summer and invoked the now familiar tropes of darkness to explain peasant resistance. Kolegaev argued that the beating and violence meted out to those trying to administer the census and grain monopoly in Koz'modem'ianskii uezd had its origins in ignorance, or 'darkness'. Kolegaev's impression was that dialogue, without the presence of soldiers, would resolve matters. ${ }^{78}$ The situation in Koz'modem'ianskii uezd by September indicates that Kolegaev's faith in education was misplaced. Despite the efforts of soviet sponsored educational campaigns, violence and resistance in the $u e z d$ continued unabated. ${ }^{79}$

The belief that ordinary people resisted government policy because they did not know or understand it proved to be surprisingly durable, even in the face of conscious and concerted resistance from ordinary people. By September, a coalition of left SRs and Bolsheviks had taken control of Kazan guberniia's provisions administration. Their attitude towards the use of armed force and arrests in the countryside was ambiguous. While in principle they supported the use of force as their predecessors had, they laboured under the delusion that resistance to grain monopoly was carried out by a minority, and that most peasants were simply unenlightened. Kolegaev, commenting on the unrest in Spasskii uezd in July reiterated 
that 'even if they are dark, they are still our comrades. We cannot go to them with armed force. ${ }^{80}$ As the summer progressed, and the grain monopoly continued to crumble, Kolegaev and his comrades came to support punitive measures in the countryside, which they justified as actions against the 'wealthy minority' that they asserted were behind the problems. The Nizhegorod soviet of workers and soldiers' deputies also called for the use of soldiers against peasants withholding grain as the summer progressed. ${ }^{81}$ This reflected a national shift towards desperate measures for grain procurement, but does not suggest that the political elite embraced coercion freely. ${ }^{82}$

\section{Conclusions}

The aims of cultural enlightenment campaigners were far-reaching and ambitious. They sought to engender a fundamental transformation of Russian sociopolitical life, using the gains of the February revolution as a starting point, and education as the lynchpin of their efforts. Their campaigns sought to bridge the gap between the perceptions of educated society, and those of 'the people'. The political elite perceived ordinary people, especially rural ordinary people, to be childlike, empty vessels that could be filled with their visions of the new revolutionary order. They did not anticipate that their education programmes would be greeted by autonomous, politically aware individuals, who would make their own political choices. Ultimately, 1917's drive for enlightenment was perceived by its main protagonists as a failure, in that ordinary people refused to endorse the Provisional Government's policies, most catastrophically on grain procurement. The political elite's attempts to educate the population on the grain monopoly exposed its failings starkly. Their problems lay not with communication, or getting ordinary people to engage in the political sphere, but in the content of their message. The political elite 
could not get ordinary people to accept perceived unfair market prices in the name of the new Russian state. The political elites blamed their failure on the darkness and ignorance of ordinary people, who were purportedly unable to understand national needs. The notion of a 'dark' people was a convenient one for the political elite, as it enabled them to blame the population for their enduring ignorance, rather than to accept that ordinary people were conscious political actors who consciously rejected the political elite's message.

The cultural enlightenment campaigns of 1917 were in many respects a continuation of the activities of pre-revolutionary educational activists, and were able to tap into increasing societal interest in education. The drive for enlightenment witnessed in 1917 was, however, on an entirely different scale to the educational campaigns that had preceded it. It involved all sectors of educated society, and utilised a diverse array of means to forward its aims. The 1917 campaign was imbued with fresh urgency, as it was apparent both to Russia's political elite and to her grassroots activists that if their vision of a democratic, ordered egalitarian Russia was to be implemented, and civil war avoided, their education campaigns had to succeed in enlightening the population. While cultural enlightenment campaigns were posited as non partisan, they actually reflected the specifically socialist climate of revolutionary Russia, and acted as a forum for political competition, and for partisan political activities.

This study of cultural enlightenment campaigns indicates that communication and alien language between educators and villagers were not the fundamental problems that educators faced. A diverse range of educational forms were utilised in cultural enlightenment activities, a major feature of which was the sweetening of educational material with music, theatre and diversions. Public holidays, especially 
May Day, were an imporant forum for cultural enlightenment campaigners. Cultural enlightenment programmes were stymied not by the language used, but by the nature of their goals, which sought a profound cultural transformation for Russia, into a society that shared the worldview and aspirations of the political elite. The political elite in 1917 did not contemplate violent means of enforcing this cultural transformation. Their avoidance of coercion rather contradicts Peter Holquist's overarching synthesis of the revolutionary period, which emphasised that willingness to rely on the power of the state was a feature of Tsarist, Provisional Government and Bolshevik administrations alike. The evidence from grassroots Kazan and Nizhegorod indicates that the local political elites stopped short of coercion in their attempts to transform Russia. Even in the face of outright hostility and threats to their safety, the political elite clung to their faith in education. Their efforts to communicate with ordinary people were a success, but enlightenment for ordinary people came in forms that the political elite had not envisaged or desired.

\section{ENDNOTES}

\section{${ }^{1}$ E. N. Medynskii, Kak vesti besedi po politicheskam voprosam: Metodicheskie} ukazaniia, konspekti i spiski literaturi dlia lektorov, uchitelei i pr (Moscow, 1917), p.3. Medynskii was an educationalist, who wrote prolific educational literature in the revolutionary period, and went on to be a leading educational theorist in the Soviet period. See also T. Iu. Krasovitskaia, Rossiiskoe obrazovanie mezhdu reformatorstvom i revoliutsionerizmom, fevral 1917-1920 god (Moscow, 2002), p.15

${ }^{2}$ I refer throughout this article to 'ordinary people' and the 'political elite', terms that are intended to facilitate understanding of communication between political 
leaders and constituents. 'Political elite' refers both to the political elite at the centre of power in Petrograd, and those individuals who were in positions of authority in regional politics. I use the term 'ordinary people' with reservations, but because it was the least judgemental and broadest way to describe those individuals who were not active in the formal political and administrative structures that developed in 1917. These terms are intended to be understood loosely, even amorphously. Some 'ordinary people' could also be described as members of the political elite, if for example they participated in local administration or leadership.

\footnotetext{
${ }^{3}$ See $\{$ Frierson 1993654 /id \}; \{Kotsonis 19991022 /id\}; \{Frank 19991230 /id \}, especially chapters 1 and 9; \{Frierson 20021231 /id $\}$

${ }^{4}$ \{Sanborn 2003993 /id\}; \{Stockdale 20041232 /id\}. See also the articles and discussion by Scott Seregny, Joshua Sanborn and Steve Smith in Slavic Review 2000, 59,2, pp. 267-342.

5 \{Retish 20051163 /id\}. See also \{Retish 20031107 /id

${ }^{6}$ See $\{$ Hickey 1996231 /id\}; \{Hickey 1996372 /id\}; \{Hickey 1996482 /id\}; \{Hickey 2001622 /id\}; \{Hickey 20011097 /id $\}$.

${ }^{7}$ In particular, see Peter Holquist, Making war, forging revolution: Russia's

continuum of crisis, 1914-1921 (Cambridge, Mass., 2002); Joshua A. Sanborn,
}

Drafting the Russian nation military conscription, total war, and mass politics, 1905 -

1925 (DeKalb, 2003); Y Kotsonis, Making Peasants Backward: Agricultural co-

operatives and the agrarian question in Russia, 1861-1914 1999); Daniel T.

Orlovsky, 'The Provisional Government and its cultural work' in A. Gleason, Peter

Kenez, and Richard Stites (eds), Bolshevik Culture. Experiment and order in the

Russian revolution (Bloomington, 1985), pp. 39-56.

${ }^{8}$ Orlovsky, 'The Provisional Government and its cultural work', pp. 39-56., pp. 44-45.

This article presents a detailed analysis of the Provisional Government's cultural policies.

${ }^{9}$ Holquist, Making war, forging revolution: Russia's continuum of crisis, 1914-1921

${ }^{10}$ Natsionalnyi Arkhiv Respublika Tatarstana (Henceforth NART), f. 1246, op. 1, d.

72, p.83; list of public organisations and parties delegating their representatives to the 
cultural enlightenment section of the soviet of workers and soldiers' deputies, undated.

${ }^{11}$ Orlovsky, 'The Provisional Government and its cultural work', pp. 39-56., p.43

${ }^{12}$ Izvestiia soveta rabochikh deputatov 41, 24 August 1917; p.3.

${ }^{13}$ E. N. Medynskii, Revoliutsiia i vneshkol'noe obrazovanie. S prilozheniem konspektov besed s krestianami na temy, sviazannym s revoliutsiei (Moscow`, 1917) p.15

${ }^{14}$ Boris I. Kolonitskii, "Democracy' as Identification: Towards the study of political consciousness during the February revolution' in Madhavan K. Palat (eds), Social identities in revolutionary Russia (London, 2001), pp. 161-173., p.161

${ }^{15}$ Based on thirty two PSR propaganda meetings that were reported in the Nizhnii Novgorod PSR newspaper Narod.

${ }^{16}$ On the development of 'people's universities', which were particularly notable in the post 1905 period, see David Wartenweiler, Civil society and academic debate in Russia, 1905-1914 (Oxford, 1999), ch. 5, pp.165-215.

${ }^{17}$ Charles Clark offers a detailed assessment of the use and pitfalls of the Bolsheviks' use of peasant reading rooms in the early Soviet period. (Charles Clark, 'Uprooting Otherness: Bolshevik Attempts to Refashion Rural Russia via the Reading Rooms', Canadian Slavonic Papers XXXVIII (1996), 305-330.)

${ }^{18}$ E. N. Medynskii, Ot temy $k$ svetu! Nashe neumyn'e i nasha bednota. Nasha temnota. kak borot'sia s nashei temnotoi (Nizhnii Novgorod, 1917) pp.29-30 ${ }^{19}$ Catriona Kelly, Refining Russia: Advice literature, polite culture, and gender from Catherine to Yeltsin (Oxford, 2001), esp. pp.189-229 on advice manuals directed towards ordinary people; Jeffrey Brooks, When Russia learned to read: Literacy and popular literature, 1861-1917 (Princeton, N.J., 1985), p.51; Gary Thurston, 'The 
impact of Russian popular theatre, 1886-1915', Journal of Modern History 55 (1983), 237-267., p.240; Anthony E. Swift, 'Workers' theater and "proletarian culture" in prerevolutionary Russia,1905-1917' in Reginald E. Zelnik (eds), Workers and intelligentsia in late Imperial Russia: Realities, representations, reflections (California, 1999), pp. 260-291., p.278

${ }^{20}$ A narodnyi dom was set up in Lysovskii uezd in commemoration of the events of 27 February, which was funded in the first instance by a private donation of 5000 roubles (Gosudarstvennyi Arkhiv Nizhegorodskoi Oblasti [henceforth GANO], f. 715, op. 1, d. 7, p.8; protocol no 4 of Lyskovskii residents committee, 7 march 1917) A narodnyi dom was similarly established by Sarleiskii volost, 'to commemorate free Russia'.(GANO, f. 830, op. 1, d. 5, p.120; declaration of Sarleiskoi volost citizens, 15 March 1917.)

${ }^{21}$ See Kotsonis, Making Peasants Backward: Agricultural co-operatives and the agrarian question in Russia, 1861-1914, p. 5

${ }^{22}$ NART, f. 1246, op. 1, d. 72, p.82; outline of programme for soviet of workers and soldiers' deputies cultural enlightenment section, undated.

${ }^{23}$ See A. Gleason, 'The terms of Russian social history' in Samuel D. Kassow, James

L. West, and Edith W. Clowes (eds), Educated Society and the Quest for Public Identity in Late Imperial Russia (Princeton, 1991), pp. 15-27., p.18.

${ }^{24}$ On the 'going to the people movement, see F. Venturi, Roots of revolution: A history of the Populist and Socialist movements in nineteenth century Russia (London, 1960) chapter 18, and Daniel Field, Rebels in the name of the Tsar (Boston, 1989).

See also C. Pape, 'On the margins of Utopia? Zemstvo liberals and the peasant commune.', Russian History-Histoire Russe 11 (1984), p.224. 
${ }^{25}$ On the significance of cultural hierarchies, see J. Neuberger, Hooliganism. Crime, culture and power in St. Petersburg, 1900-1914. (London, 1993), pp.10-11; Stephen P. Frank, 'Confronting the domestic Other: Rural popular culture and its enemies in fin de siecle Russia.' in Stephen P. Frank and Mark D. Steinberg (eds), Cultures in Flux: Lower class values, practices and resistance in late Imperial Russia (Princeton, 1994), pp. 74-107.; Thurston, 'The impact of Russian popular theatre, 1886-1915', 237-267., p.251.

${ }^{26}$ Judy Pallot, 'Imagining the rational landscape in late Imperial Russia', Journal of Historical Geography 26 (2000), 273-291., pp.273-275; addresses this idea in relation to government involvement in land reform.

${ }^{27}$ E. E. Pyle, 'Peasant strategies for obtaining State aid: A study of petitions during World War One', Russian History-Histoire Russe 24 (1997), 41-64.; on the formulaic ways in which soldiers' families presented themselves in petitions to the state. Andrew Verner, 'Discursive strategies in the 1905 Revolution: Peasant petitions from Vladimir province', Russian Review 54 (1995), 65-90., offers a detailed analysis of peasant petitions in Vladimir province, and suggests that peasants 'consciously manipulated' language. (p. 70) Seregny (Scott J. Seregny, 'Peasants, nation, and local government in wartime Russia', Slavic Review 59 (2000), 336-342., p.340) comments on the way in which peasants subscribed to official discourses.

${ }^{28}$ Izvestiia soveta rabochikh deputatov 19, 1 June 1917, p.2

${ }^{29}$ Jeffrey Burds, Peasant Dreams and Market Politics: Labour migration and the Russian Village, 1861-1905 (Pittsburgh, 1998); Verner, 'Discursive strategies in the 1905 Revolution: Peasant petitions from Vladimir province', 65-90., esp. pp.72-73. 
${ }^{30}$ Scott J. Seregny, 'Power and discourse in Russian elementary education: The school inspectorate, 1869-1917', Jahrbucher fur Geschichte Osteuropas 47 (1999), 161-186., p.167.

${ }^{31}$ Sanborn, Drafting the Russian nation military conscription, total war, and mass politics, $1905-1925$, p.19

${ }^{32}$ Scott J. Seregny, 'Zemstvos, peasants, and citizenship: The Russian adult education movement and World War I', Slavic Review 59 (2000), 290-315., esp. p.312.

${ }^{33}$ See Seregny, 'Zemstvos, peasants, and citizenship: The Russian adult education movement and World War I', 290-315., esp. pp. 310, 312.

34 The 1897 census gives some indications of the weighting of literacy according to age. Women over thirty had literacy levels of less than $20 \%$, though literacy increased significantly among those under thirty. (U. A. Poliakov, Naselenie Rossii v XX veke: Istoricheskie ocherki. Tom 1. (Moscow, 2000)], p.23.)

${ }^{35}$ GANO, f. 815, op. 1, d. 19, p.1; report from Khvostikovskii volost elder, early March 1917.

${ }^{36}$ GANO, f. 815, op. 1, d. 19, p.2; list of members of Khvostikovskii volost Executive committee, undated.

37 Hickey 1996372 /id

${ }^{38}$ Orlando Figes, 'The Russian revolution and its language in the villages', Russian Review 56 (1997), 323-345. Figes utilises a single educational pamphlet written by Medynskii, and the reports submitted to the Provisional Committee of the State Duma, which have been published in a number of forms, but which are currently held in RGIA. These reports, while a rich and lively source on the state of the countryside in 1917 , are not definitive, as reporters' views of rural life did not necessarily reflect 'objective reality'. (RGIA, f. 1278, op. 1, d. 4, pp.240-256; Report on the situation of 
Russia for three months of revolution by the current section of relations with the provinces of the Provisional Committee of the State Duma.) On the need to treat outsider sources on peasant life with caution, see Verner, 'Discursive strategies in the 1905 Revolution: Peasant petitions from Vladimir province', 65-90., p.65

${ }^{39}$ Medynskii, Kak vesti besedi po politicheskam voprosam: Metodicheskie ukazaniia, konspekti i spiski literaturi dlia lektorov, uchitelei i pr, p.4

${ }^{40}$ Medynskii, Kak vesti besedi po politicheskam voprosam: Metodicheskie ukazaniia, konspekti i spiski literaturi dlia lektorov, uchitelei i pr, p.8

${ }^{41}$ Robert Geraci, Window on the east: National and Imperial identities in late Tsarist Russia (Cornell, 2001), p.28

${ }^{42}$ Kazanskaia rabochaia gazeta 45, 4 June 1917, p.3

${ }^{43}\{$ Retish 20051163 /id $\}$

${ }^{44}$ Frank, 'Confronting the domestic Other: Rural popular culture and its enemies in fin de siecle Russia.', pp. 74-107., p.95ff. Thurston, 'The impact of Russian popular theatre, 1886-1915', 237-267.; Von Geldern, Entertaining Tsarist Russia (Bloomington, 2000), pp.275-6

${ }^{45}$ Kazanskaia rabochaia gazeta 13, 25 April 1917

${ }^{46}$ Izvestiia Soveta rabochikh i soldatskikh deputatov 18, 28 May 1917, p.1

${ }^{47}$ Kazanskaia rabochaia gazeta 123, 12 September 1917, p.3

${ }^{48}$ Kazanskaia rabochaia gazeta 12, 23 April, p.1

${ }^{49}$ Kazanskaia rabochaia gazeta 13, 25 April 1917, p.2

${ }^{50}$ Kazanskaia rabochaia gazeta 16, 28 April 1917, p.3

${ }^{51}$ Kazanskaia rabochaia gazeta, had a regular reviews column. no. 133, 24

September 1917, just as an example. 
${ }^{52}$ See Thurston, 'The impact of Russian popular theatre, 1886-1915', 237-267.; Swift,

'Workers' theater and "proletarian culture" in prerevolutionary Russia,1905-1917', pp. 260-291., p.275.

${ }^{53}$ Von Geldern, Entertaining Tsarist Russia, p.276

${ }^{54}$ Izvestiia Tambovskago soveta rabochikh, soldatskikh i krestianskikh deputatov 119, 24 August 1917

${ }^{55}$ Orlando Figes and Boris I. Kolonitskii, Interpreting the Russian Revolution- The Language and Symbols of 1917 (New Haven, 1999), p.46

${ }^{56}$ Izvestiia soveta rabochikh $i$ soldatskikh deputatov 6, 9 April 1917, p.4

${ }^{57}$ See Swift, 'Workers' theater and "proletarian culture" in prerevolutionary Russia,1905-1917', pp. 260-291., p.280.

${ }^{58}$ Page Herrlinger, 'Prayer as women's work: The feminisation of faith in the Russian factory, 1880-1917' (Conference paper given at Labour history of Russia and the Soviet Union: Work in progress, Amsterdam, 2005), pp.8-9

${ }^{59}$ E. N. Medynskii, Kak organizovat $i$ vesti selskie prosvetitel'nye obshchestva $i$ kruzhki (Nizhnii Novgorod, 1918)esp. pp.6-8

${ }^{60}$ N. N. Sukhanov, 'Iz proshlogo; etiudi fevralskoi revoliutsii', Kommunisticheskii Put 2 (1923), 61-65., p.62

${ }^{61}$ Izvestiia Soveta rabochikh i soldatskikh deputatov 4824 September, pp.2-3

${ }^{62}$ Kazanskaia rabochaia gazeta, 26, 11 May 1917, p.4: letter from Posen defending his musical programme.

${ }^{63}$ Brooks, When Russia learned to read: Literacy and popular literature, 1861-1917, p.33

${ }^{64}$ For example, Sukhanov, 'Iz proshlogo; etiudi fevralskoi revoliutsii', 61-65., p.62:

Sukhanov was a deserting soldier who was based in Saralovskii volost, Laishevskii 
uezd, Kazan guberniia, and he described the demonstration arranged by him and some visiting student agitators.

${ }^{65}$ Izvestiia soveta soldatskikh i rabochikh deputatov 19, 1 June 1917, p.1: report from soviet deputies' journey around the uezds.

${ }^{66}$ Aaron Retish shows similar events in Viatka. A. Retish, 'Peasant identities in Russia's Turmoil: Status, gender and ethnicity in Viatka province, 1914-1921', unpublished PhD thesis, Ohio State University (2003), pp.123-124

${ }^{67}$ Rossiiskie Gosudarstvennyi Arkhiv Sotsialnoi I politicheskoi Istorii (Henceforth RGASPI), f. 274, op. 1, d. 26, p.112. Excerpt from Zinovii Magergut's memoir, entitled "writings-recollections of a member of the Sormovskii organisation of the PSR, from April 1916 to April 1917’

${ }^{68}$ Gosudarstvennyi Arkhiv Rossiisskoi Federatsii (henceforth GARF), f. 9591c., op. 1, d. 11, p.13. Xeroxed three page leaflet, first page missing, signed by Tiurikov, undated.

${ }^{69}$ There were a number of well-known Mensheviks in Kazan, including Iu.P. Denike, who worked for unity of the Social Democrats.

${ }^{70}$ K. Magnov, 'Dni Oktiabria', Kommunisticheskii Put 12 (1922), 98-117., p.99

${ }^{71}$ A. Rakhmatullin, 'Mulla-Nur Vakhitov', Kommunisticheskii Put 11 (1922), 34-40., p.37

${ }^{72}$ NART, f. 1246, op. 1, d. 75, p.53; letter from Kazanskii uezd provisions administration to Kazan guberniia provisions committee, 12 July 1917; p.60, telegram from uezd commissar to guberniia commissar, 19 July 1917; Kazanskaia rabochaia gazeta 86, 26 July 1917, p.4.

${ }^{73}$ Kazanskaia rabochaia gazeta 100, 12 August 1917, p.4 
${ }^{74}$ NART, f. 1246 , op. 1, d. 75, p.295, report from Kazan uezd commissar to guberniia commissar, September 1917.

${ }^{75}$ NART f. 1246, op. 1, d. 44, pp.52-57; journal of the meeting of Iadrinskii uezd committee and soviet, 10 July 1917.

${ }^{76}$ Kazanskaia rabochaia gazeta 87, 27 July 1917, p.3; A more detailed report of events produced in Kazanskaia rabochaia gazeta 109, 24 August 1917, p.4

${ }^{77}$ Kazanskaia rabochaia gazeta 73, 11 July 1917, p.3

${ }^{78}$ Izvestiia Kazanskago gubernskago soveta krestianskikh deputatov 14, 18 August 1917, pp.2-3

${ }^{79}$ Kazanskaia rabochaia gazeta 128, 19 September 1917, p.4

${ }^{80}$ Izvestiia Kazanskago gubernskago soveta krestianskikh deputatov 8, 28 July 1917.

${ }^{81}$ Izvestiia soveta rabochikh $i$ soldatskikh deputatov 53, 12 October 1917, p.4:

meeting of EC soviet of workers and soldiers' deputies, 9 October.

${ }^{82}$ George L. Yaney, The Urge to Mobilise. Agrarian reform in Russia 1861-1930

(London, 1982), p.442 